\title{
Stability Analysis of Piles Subjected to Lateral Load in Static and Seismic Conditions
}

José Medina, Nicolás Sau, Qutberto Acuña and Jesús Quintana

Department of Civil Engineer and Mining, University of Sonora, Hermosillo, Sonora 83000, México

\begin{abstract}
It is disclosed a method for the stability analysis of foundation piles and piers subjected to lateral loading, both static and seismic conditions. The stability analysis for stratified soil is based upon the models of foundation soil-structure interaction and the Rankine's theory of earth passive pressure. In addition, its application is simpler and it can be solved using a spreadsheet. The procedure described in this work can be used in homogeneous soils as in stratified soils, considers the horizontal drag forces exerted by the soil mass against the foundation during an earthquake, can be used easily in the four pile and piers boundary cases, and considers the pore pressure generated in a fine saturated soil during an earthquake or during a rapid application of the horizontal load. The solution of two examples are shown, one in static condition and one in seismic condition, detailing the procedure step by step.
\end{abstract}

Key words: Ultimate lateral resistance of piles and piers, lateral bearing capacity of piles and piers, piles, piers, soil-structure interaction in piles and piers.

\section{Introduction}

In a deep foundation subjected to lateral loading, it should be checked that the supporting soil is able to withstand the contact pressure induced by the foundation to the soil mass. This article presents a method for the analysis of stability of foundation piles and piers subjected to lateral loading, both in static and seismic conditions. The stability analysis for stratified soil is based upon the models of foundation soil-structure interaction proposed by Medina [1-4] as well as in the Rankine's theory of earth passive pressure [5]. This methodology has the advantage that it considers the excessive hydrostatic pressure that is generated in a fine saturated soil during a seismic event. In addition, its application is simpler and it can be solved using a spreadsheet.

\section{Ultimate Lateral Resistance}

According to Rankine theory shown in Terzaghi [5], the passive horizontal stress is determined by Eqs. (1)

Corresponding author: José Medina, M. Eng./professor, research fields: foundation and geotechnical engineering. E-mail: jose.medina@prolas.com.mx. and (2):

$$
\begin{gathered}
\sigma_{h}^{\prime}=N \varphi \sigma_{z}^{\prime}+2 C \sqrt{N \varphi} \\
N \varphi=\tan ^{2}\left(45^{\circ}+\varphi / 2\right)
\end{gathered}
$$

where, $\sigma_{h}^{\prime}$ is the horizontal effective stress, $\sigma_{z}^{\prime}$ is the vertical effective stress, $C$ is the material cohesion, and $\varphi$ is the soil internal friction angle.

For a pile subjected to a lateral force $P$ and a moment $M$ (Fig. 1), the ultimate lateral resistance of a layered soil is determined by Eq. (3):

$$
Q_{L U}=\sum_{0}^{Z P}\left[N \varphi_{i} \sigma_{Z M i}^{\prime}+2 C_{i} \sqrt{N \varphi_{i}}\right] H_{i} D
$$

where, $Q_{L U}$ is the ultimate lateral resistance of the pile, $N \varphi_{i}$ is the $i$-th layer passive coefficient, $\sigma_{Z M i}^{\prime}$ is the vertical effective average stress at the center of the $i$-th layer. $C_{i}$ is the cohesion and $H_{i}$ is the thickness of the $i$-th layer, $D$ is the diameter of the pile or pier. $Z P$ is the depth of the passive region (Fig. 1).

The factor of safety against the foundation passive failure is determined by Eq. (4):

$$
F s=\frac{Q_{L U}}{\sum_{0}^{Z P} R_{i}} \geq 2.5
$$

where, $\sum_{0}^{Z P} R_{i}$ is the sum of the soil-foundation contact reactions to the depth $Z P$. 


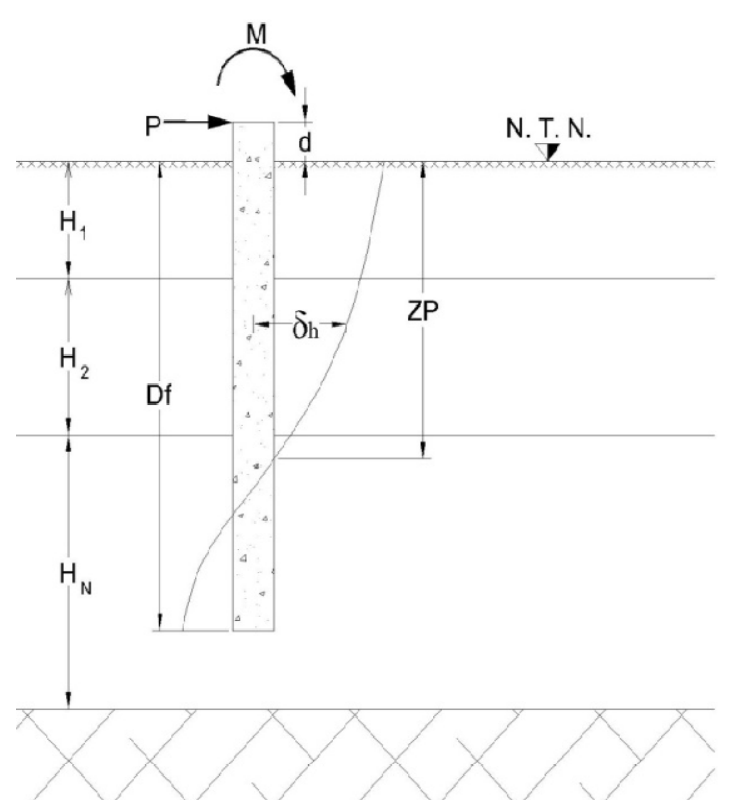

Fig. 1 Pile placed upon a layered soil.

To ensure that the foundation is stable to lateral load, it should be checked that the lateral displacement of the foundation complies with the stipulated maximum value in the project. In addition, it should be verified that it complies with the maximum allowable slope of the superstructure.

In pile groups, it should also be considered the stability of the group against lateral load, which it may be carried out with the same procedure described herein, but considering the rotation of the pile group as

CASE I

CASE II a rigid body, so that the soil-structure interaction analysis is considerably simplified.

\section{Soil-Foundation Structure Interaction}

The passive zone depth $Z P$ and the lateral contact soil-foundation reactions can be determined by the methods of soil-structure interaction for piles and piers, distinguishing the following boundary cases (Fig. 2):

Case I: It occurs when a pile or an isolated foundation pier exists and the foundation tip does not penetrate the resistant stratum. In this condition, it is considered that the foundation is free to rotate on both ends. The solution of this case is available at Medina[1].

Case II: When the pile or pier is embedded in the head and it can rotate freely on the base. The pile is cast integrally with the foundation structure. The head of the pile may or may not have a restricted rotation due to the deformation of the material that surrounds the top of the pile. The solution of this case can be found in Medina [4].

Case III: When the pile or pier can freely rotate at its upper end and is fixed at its base. The foundation tip penetrates the resistant layer. The base of the foundation can or cannot have a restricted rotation, due to deformation of the material surrounding the tip of the foundation. The solution of this case can be found

CASE IV

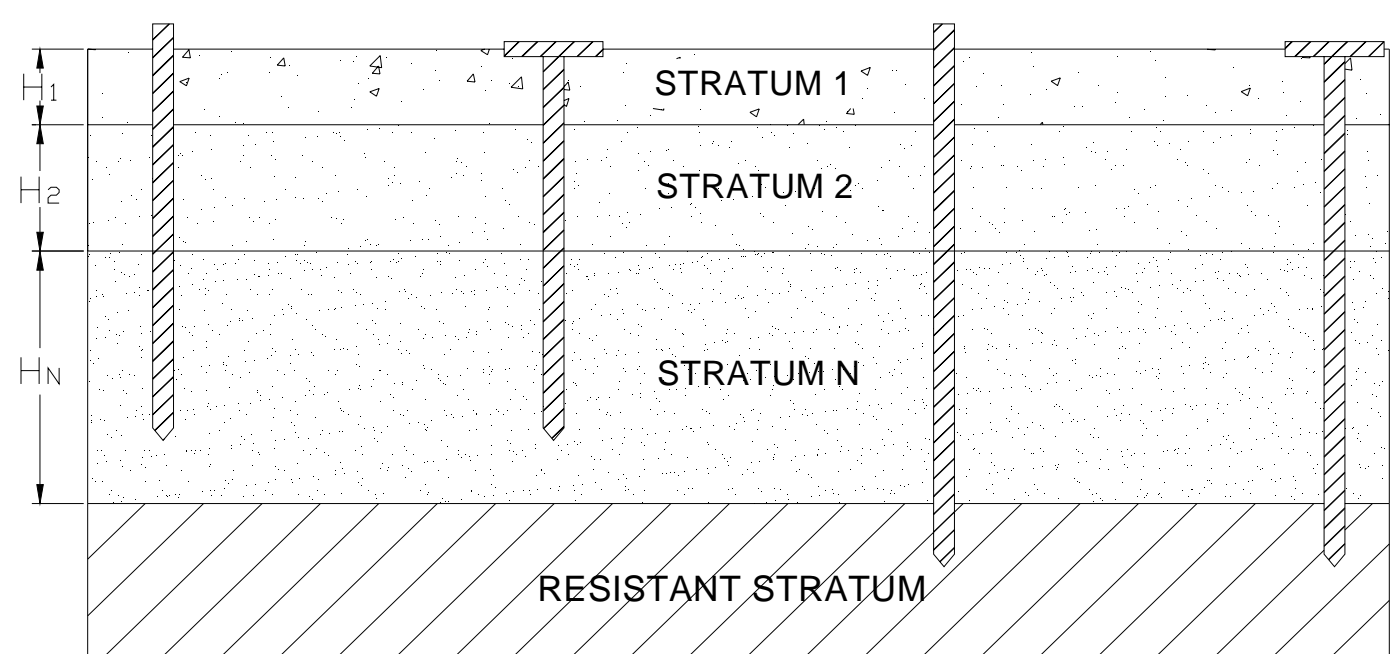

Fig. 2 Different boundary conditions cases in piles and piers. 
in Medina [2].

Case IV: In this case, the foundation is fixed at both ends. The pile or pier is cast integrally with the foundation structure and the tip penetrates the resistant stratum. Both the head and the tip of the foundation may or may not have a restricted rotation due to deformation of the material surrounding the ends of the foundation. The solution can be found in Medina [3].

\section{Example of a Pile in Static Condition}

\subsection{Statement of the Problem}

The stability analysis for a pier with the following features was developed:

Pier foundation using Case I, $E I=4.8168 \mathrm{E}+06 \mathrm{kN} / \mathrm{m}^{2}$ ( $E$ is the Young's modulus of reinforced concrete and $I$ is the moment of inertia of the cross section of the pier). $P=230 \mathrm{kN} ; M=180 \mathrm{kN}-\mathrm{m} ; d=0.50 \mathrm{~m} ; D=1.40 \mathrm{~m}$; and $D f=6.00 \mathrm{~m}$.

Considering the subsoil characteristics shown in Table 1, with a Poisson's ratio of subsoil, $v=0.3$ and assuming that it is a soil deposit in arid zones, where there is no groundwater level in the subsoil foundation. It is considered that there is a permitted maximum lateral displacement of $20 \mathrm{~mm}$ and an inclination with respect to the vertical of no more than $1^{\circ}$.

\subsection{Solution}

\subsubsection{Soil-Foundation Structure Interaction}

The soil-foundation structure interaction was conducted according to Medina [1]. The methodology consists on dividing the foundation pile in dowels $a, 1$,
$2, . ., \mathrm{n}$ and $b$ and the soil mass in the sections $\mathrm{A}, \mathrm{B}, \mathrm{C}, \ldots$, and $\mathrm{F}$ (Fig. 3). Zeevaert [6], with the application of the flexibility method to the soil mass, obtains the horizontal displacements matrix equation (5).

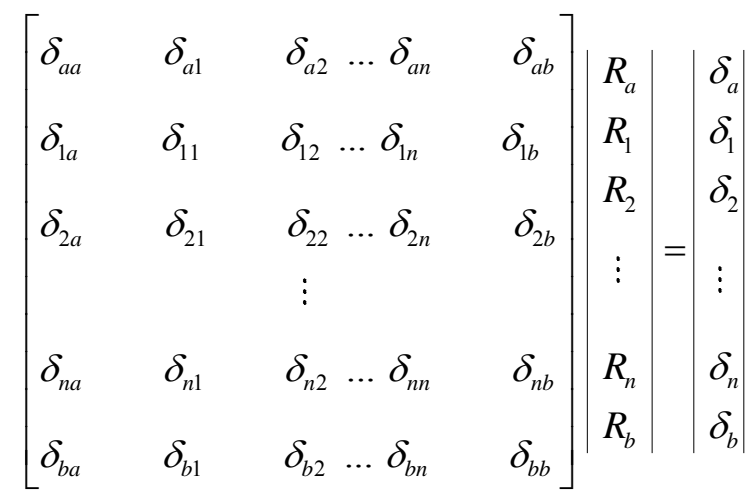

$R_{\mathrm{i}}$ is the horizontal reaction in the dowel $\mathrm{i}$.

$\delta_{i}$ is the lateral displacement in the dowel $\mathrm{i}$.

$\delta_{j i}$ is the lateral displacement in the center of slice $\mathrm{j}$, produced by a unitary load acting upon slice $\mathrm{i}, R_{i}$ is the reaction in the dowel $i$ and $\delta i$ is the lateral displacement of the dowel i.

$\delta_{j i}$ is obtained with equation (6):

$$
\begin{gathered}
\delta_{j i}=\left[I_{j i}^{A} \alpha_{i}^{A}+I_{j i}^{B} \alpha_{i}^{B}+\ldots+I_{j i}^{F} \alpha_{i}^{F}\right] / a_{i} \\
\alpha_{i}^{N}=M_{h i}^{N} \Delta x
\end{gathered}
$$

$M_{h i}^{N}$ is the soil deformation modulus; $\Delta x$ is the width of the section of soil; $a_{i}$ is the area of slice $i$.

$I_{j i}^{N}$ is the influence upon the center of slice $\mathrm{j}$, produced by a unit load acting upon slice $i$ and upon the center of section $\mathrm{N}$. The influence values are obtained with the proposed equation by Zeevaert [6] and improved by Medina [7].

\begin{tabular}{|c|c|c|c|c|c|c|}
\hline & Depth (m) & Decrintion & $M h$ & $\gamma_{m}$ & C & $\varphi$ \\
\hline \multirow[t]{5}{*}{ Ground Level } & 0.00 & Descrippion & $\left(\mathrm{m}^{2} / \mathrm{kN}\right)$ & $\left(\mathrm{kN} / \mathrm{m}^{3}\right)$ & $\left(\mathrm{kN} / \mathrm{m}^{2}\right)$ & $\left({ }^{\mathrm{O}}\right)$ \\
\hline & 1.50 & Clayey coarse sand & $1.9750 \mathrm{E}-04$ & 18.142 & 15.298 & 34 \\
\hline & 3.50 & Clayey coarse sand & $1.7375 \mathrm{E}-04$ & 18.338 & 18.437 & 34 \\
\hline & 7.00 & Clayey coarse sand & $1.5125 \mathrm{E}-04$ & 19.123 & 19.613 & 35 \\
\hline & 10.00 & Rock layer & & 22.555 & & \\
\hline
\end{tabular}

Table 1 Foundation subsoil characteristics corresponding to Example 4.

$M h$ is the soil deformation modulus, $\gamma_{m}$ is the unit weight, $C$ is the cohesion and $\varphi$ is the internal friction angle. 


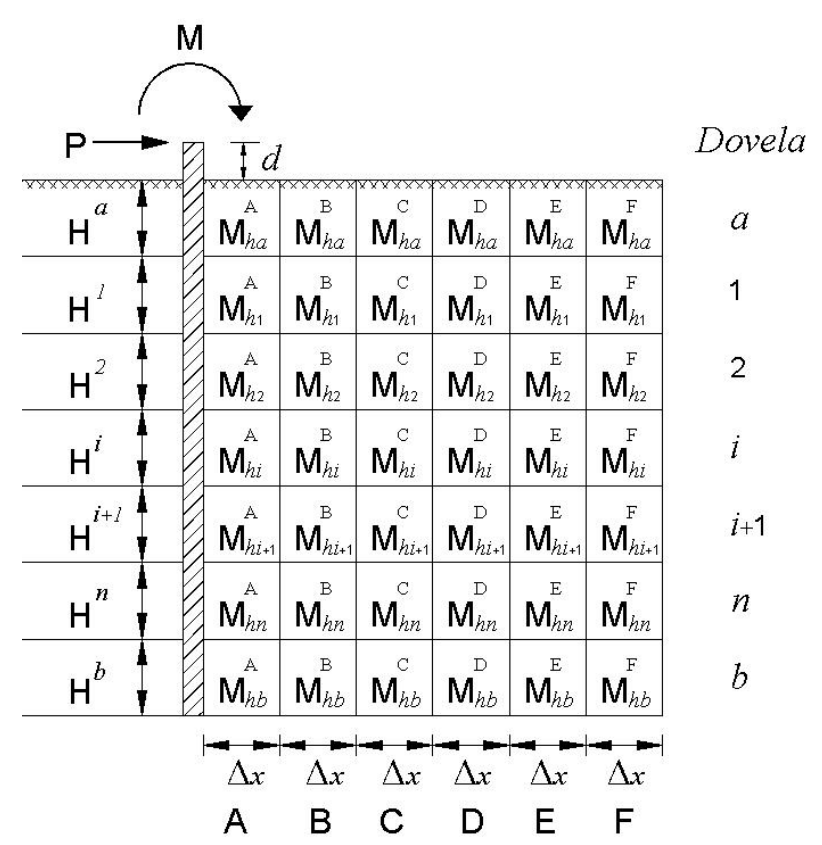

Fig. 3 Foundation and soil mass discretization.

With the application of the flexibility method to the foundation structure, (Fig. 4), Medina [1], the flexibility matrix equation (8) is obtained.

$\left[\begin{array}{cccc}d_{11} & d_{12} & \ldots & d_{1 n} \\ d_{21} & d_{22} & \ldots & d_{2 n} \\ & \vdots & \\ d_{n 1} & d_{n 2} & \ldots & d_{n n}\end{array}\right]\left|\begin{array}{c}R_{1} \\ R_{2} \\ \vdots \\ R_{n}\end{array}\right|=\left|\begin{array}{c}\Delta_{1} \\ \Delta_{2} \\ \vdots \\ \Delta_{n}\end{array}\right|+\left|\begin{array}{c}\delta_{1}^{A} \\ \delta_{2}^{A} \\ \vdots \\ \delta_{n}^{A}\end{array}\right|-\left|\begin{array}{c}\delta_{1} \\ \delta_{2} \\ \vdots \\ \delta_{n}\end{array}\right|$ $d_{j i}$ is the deflection in $\mathrm{j}$ due to a unitary load applied at $\mathrm{i}$ (condition $R_{\mathrm{i}}=1$ ); $\Delta_{\mathrm{i}}$ is the deflection at point $\mathrm{i}$ for condition $R_{\mathrm{i}}=0$ and $\delta_{i}^{A}$ is the displacement at point i, by deformation of the supports $a$ y $b$, considered the pier as a rigid body.

Note that with matrix Equations (5) and (8) there are $2 n+2$ equations with $2 n+4$ unknowns, therefore the two remaining equations are obtained from the sum of moments at supports $a$ and $b$ with which the system of equations can be resolved, obtaining the equations (9) to (11).

By the sum of moments at the supports $a$ and $b$ :

$$
\begin{gathered}
R_{a}=R_{a 0}-\left(\psi_{1} R_{1}+\psi_{2} R_{2}+\ldots+\psi_{n} R_{n}\right) \\
R_{b}=R_{b 0}-\left(\xi_{1} R_{1}+\xi_{2} R_{2}+\ldots+\xi_{n} R_{n}\right) \\
\psi_{i}=\mathrm{y}^{\prime}{ }_{i} / \mathrm{L}^{\prime} ; \quad \xi_{i}=\mathrm{z}_{i}^{\prime} / \mathrm{L}^{\prime}
\end{gathered}
$$

where, $y_{i}^{\prime}, z_{i}^{\prime}$ are the position coordinates of point $i$ and $\mathrm{L}^{\prime}$ is the distance -center to center- between slices $a$ and $b$ (Fig. 4).

$R_{a 0}$ and $R_{b 0}$ are the reactions at the supports $a$ and $b$, respectively, for condition $R_{i}=0$ (Fig. 4).

From equations (5) are obtained: $\delta_{a}, \delta_{1}, \delta_{2}, \ldots, \delta_{\mathrm{n}}$ and $\delta_{b}$.

The problem was solved by a computer program developed in a spreadsheet.

Foundation pier was divided into eight segments: $a$,

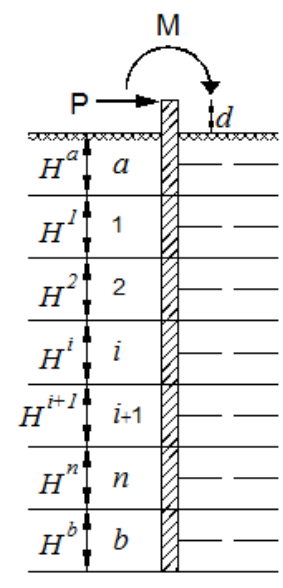

(a)

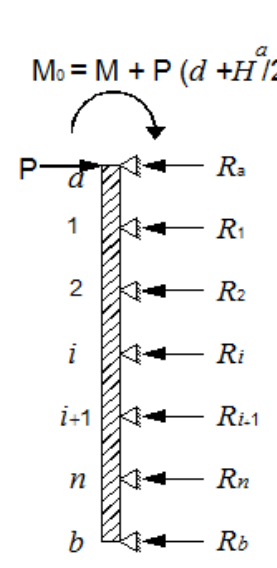

(b)

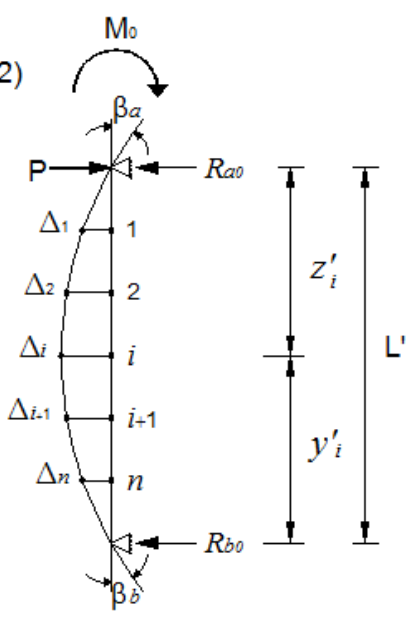

(c)

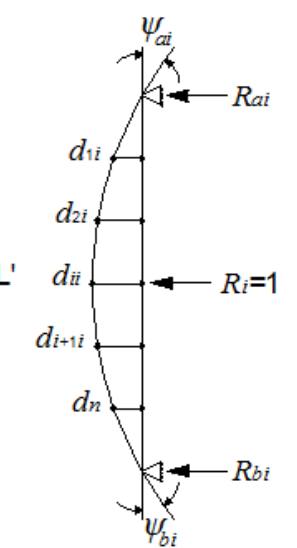

(d)

Fig. 4 Application of the flexibilities method: a) real foundation; b) discreteness of foundation; c) condition $R_{i}=0$; d) condition $\mathbf{R}_{\mathbf{i}}=1$. 
$1,2,3,4,5,6$ and $b$. It was chosen a value of $\Delta \mathrm{x}=2.10$ $\mathrm{m}$ and six sections in the soil mass: A, B, C, D, E and F. Discretization of the foundation and soil mass are shown in Table 2.

Table 3 shows the unitary lateral displacements matrix $\left[\delta_{j i}\right]$.Table 4 shows the matrix $\left[d_{j i}\right]$; Table 5 shows the matrix $\left[m_{j i}\right]$; Table 6 shows the vectors $\mathrm{N}_{\mathrm{i}}$ and $\Delta_{\mathrm{i}}$

Table 3 Unitary lateral displacements matrix, $\left[\delta_{j i}\right](\mathbf{m} / \mathbf{k N})$.

\begin{tabular}{llllllll}
\hline$a$ & 1 & 2 & 3 & 4 & 5 & 6 & $b$ \\
\hline $9.0916 \mathrm{E}-05$ & $4.5826 \mathrm{E}-05$ & $2.1267 \mathrm{E}-05$ & $1.3411 \mathrm{E}-05$ & $9.4665 \mathrm{E}-06$ & $6.7703 \mathrm{E}-06$ & $4.8351 \mathrm{E}-06$ & $3.5456 \mathrm{E}-06$ \\
$4.5826 \mathrm{E}-05$ & $7.0746 \mathrm{E}-05$ & $4.1064 \mathrm{E}-05$ & $1.9291 \mathrm{E}-05$ & $1.1825 \mathrm{E}-05$ & $7.9969 \mathrm{E}-06$ & $5.5424 \mathrm{E}-06$ & $3.9916 \mathrm{E}-06$ \\
$1.8793 \mathrm{E}-05$ & $3.6291 \mathrm{E}-05$ & $6.0191 \mathrm{E}-05$ & $3.6254 \mathrm{E}-05$ & $1.6414 \mathrm{E}-05$ & $9.3361 \mathrm{E}-06$ & $6.0428 \mathrm{E}-06$ & $4.2088 \mathrm{E}-06$ \\
$1.1820 \mathrm{E}-05$ & $1.7062 \mathrm{E}-05$ & $3.6254 \mathrm{E}-05$ & $5.9060 \mathrm{E}-05$ & $3.5436 \mathrm{E}-05$ & $1.4749 \mathrm{E}-05$ & $8.0547 \mathrm{E}-06$ & $5.2945 \mathrm{E}-06$ \\
$8.3368 \mathrm{E}-06$ & $1.0425 \mathrm{E}-05$ & $1.6414 \mathrm{E}-05$ & $3.5436 \mathrm{E}-05$ & $5.8453 \mathrm{E}-05$ & $3.1735 \mathrm{E}-05$ & $1.2379 \mathrm{E}-05$ & $7.1066 \mathrm{E}-06$ \\
$5.1805 \mathrm{E}-06$ & $6.1172 \mathrm{E}-06$ & $8.0914 \mathrm{E}-06$ & $1.2690 \mathrm{E}-05$ & $2.7309 \mathrm{E}-05$ & $4.9236 \mathrm{E}-05$ & $2.4556 \mathrm{E}-05$ & $9.8723 \mathrm{E}-06$ \\
$3.7004 \mathrm{E}-06$ & $4.2411 \mathrm{E}-06$ & $5.2494 \mathrm{E}-06$ & $6.9855 \mathrm{E}-06$ & $1.0674 \mathrm{E}-05$ & $2.4556 \mathrm{E}-05$ & $4.9023 \mathrm{E}-05$ & $2.4396 \mathrm{E}-05$ \\
$2.7138 \mathrm{E}-06$ & $3.0549 \mathrm{E}-06$ & $3.6585 \mathrm{E}-06$ & $4.6000 \mathrm{E}-06$ & $6.1666 \mathrm{E}-06$ & $9.8723 \mathrm{E}-06$ & $2.4396 \mathrm{E}-05$ & $4.8901 \mathrm{E}-05$ \\
\hline
\end{tabular}

Table 4 Matrix, $\left[d_{j i}\right](\mathbf{m} / \mathbf{k N})$.

\begin{tabular}{llllll}
\hline 1 & 2 & 3 & 4 & 5 & 6 \\
\hline $1.4855 \mathrm{E}-07$ & $2.3359 \mathrm{E}-07$ & $2.6205 \mathrm{E}-07$ & $2.4954 \mathrm{E}-07$ & $1.9753 \mathrm{E}-07$ & $1.0741 \mathrm{E}-07$ \\
$2.3359 \mathrm{E}-07$ & $3.9737 \mathrm{E}-07$ & $4.6281 \mathrm{E}-07$ & $4.4859 \mathrm{E}-07$ & $3.5882 \mathrm{E}-07$ & $1.9623 \mathrm{E}-07$ \\
$2.6205 \mathrm{E}-07$ & $4.6281 \mathrm{E}-07$ & $5.7040 \mathrm{E}-07$ & $5.7216 \mathrm{E}-07$ & $4.6665 \mathrm{E}-07$ & $2.5783 \mathrm{E}-07$ \\
$2.4954 \mathrm{E}-07$ & $4.4859 \mathrm{E}-07$ & $5.7216 \mathrm{E}-07$ & $6.0476 \mathrm{E}-07$ & $5.1174 \mathrm{E}-07$ & $2.8807 \mathrm{E}-07$ \\
$1.9753 \mathrm{E}-07$ & $3.5882 \mathrm{E}-07$ & $4.6665 \mathrm{E}-07$ & $5.1174 \mathrm{E}-07$ & $4.6295 \mathrm{E}-07$ & $2.7232 \mathrm{E}-07$ \\
$1.0741 \mathrm{E}-07$ & $1.9623 \mathrm{E}-07$ & $2.5783 \mathrm{E}-07$ & $2.8807 \mathrm{E}-07$ & $2.7232 \mathrm{E}-07$ & $1.7661 \mathrm{E}-07$ \\
\hline
\end{tabular}

Table 5 Matrix, $\left[m_{j i}\right](\mathbf{m} / \mathbf{k N})$.

\begin{tabular}{llllll}
\hline 1 & 2 & 3 & 4 & 5 & 6 \\
\hline$-1.1065 \mathrm{E}-05$ & $6.2932 \mathrm{E}-06$ & $9.5147 \mathrm{E}-06$ & $9.2990 \mathrm{E}-06$ & $7.2856 \mathrm{E}-06$ & $2.6421 \mathrm{E}-06$ \\
$8.4802 \mathrm{E}-06$ & $2.1181 \mathrm{E}-05$ & $2.2043 \mathrm{E}-05$ & $1.9915 \mathrm{E}-05$ & $1.5722 \mathrm{E}-05$ & $7.3866 \mathrm{E}-06$ \\
$1.0939 \mathrm{E}-05$ & $2.1648 \mathrm{E}-05$ & $2.2541 \mathrm{E}-05$ & $2.0864 \mathrm{E}-05$ & $1.7153 \mathrm{E}-05$ & $8.1568 \mathrm{E}-06$ \\
$1.0307 \mathrm{E}-05$ & $1.9399 \mathrm{E}-05$ & $2.0677 \mathrm{E}-05$ & $1.9804 \mathrm{E}-05$ & $1.6974 \mathrm{E}-05$ & $7.7585 \mathrm{E}-06$ \\
$8.8375 \mathrm{E}-06$ & $1.6117 \mathrm{E}-05$ & $1.7831 \mathrm{E}-05$ & $1.7869 \mathrm{E}-05$ & $1.6033 \mathrm{E}-05$ & $6.5776 \mathrm{E}-06$ \\
$3.8212 \mathrm{E}-06$ & $7.8044 \mathrm{E}-06$ & $8.7980 \mathrm{E}-06$ & $8.6410 \mathrm{E}-06$ & $6.5533 \mathrm{E}-06$ & $-4.6770 \mathrm{E}-06$ \\
\hline
\end{tabular}

$$
\left[\left[\begin{array}{cccc}
\delta_{11} & \delta_{12} & \ldots & \delta_{1 n} \\
\delta_{21} & \delta_{22} & \ldots & \delta_{2 n} \\
& \vdots & & \\
\delta_{n 1} & \delta_{n 2} & \ldots & \delta_{n n}
\end{array}\right]+\left[\begin{array}{cccc}
d_{11} & d_{12} & \ldots & d_{1 n} \\
d_{21} & d_{22} & \ldots & d_{2 n} \\
& \vdots & & \\
d_{n 1} & d_{n 2} & \ldots & d_{n n}
\end{array}\right]+\left[\begin{array}{cccc}
m_{11} & m_{12} & \ldots & m_{1 n} \\
m_{21} & m_{22} & \ldots & m_{2 n} \\
& \vdots & & \\
m_{n 1} & m_{n 2} & \ldots & m_{n n}
\end{array}\right]\right]\left|\begin{array}{c}
R_{1} \\
R_{2} \\
\vdots \\
R_{n}
\end{array}\right|=\left|\begin{array}{c}
n_{1} \\
n_{2} \\
\vdots \\
n_{n}
\end{array}\right|+\left|\begin{array}{c}
\Delta_{1} \\
\Delta_{2} \\
\vdots \\
\Delta_{n}
\end{array}\right|
$$

where: 


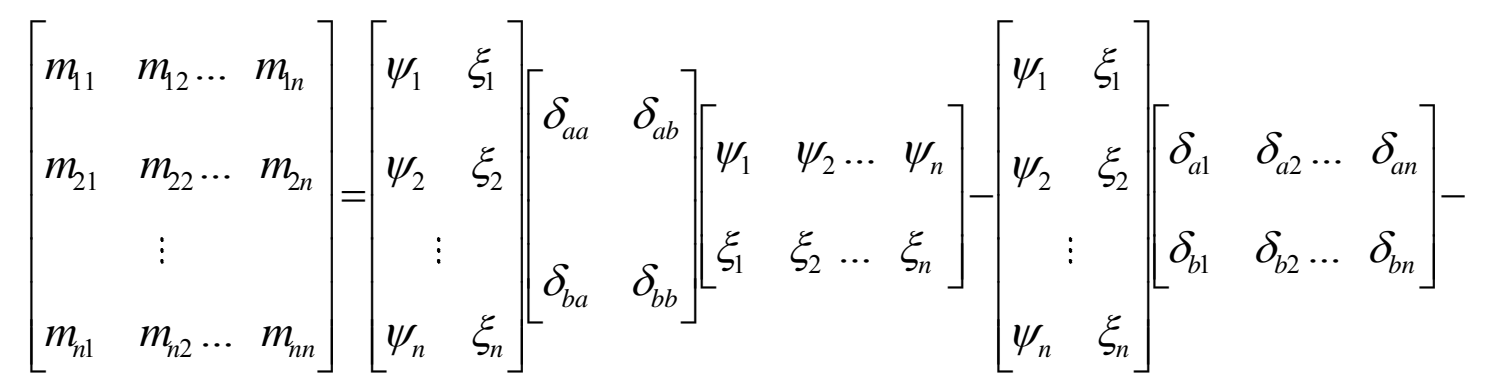

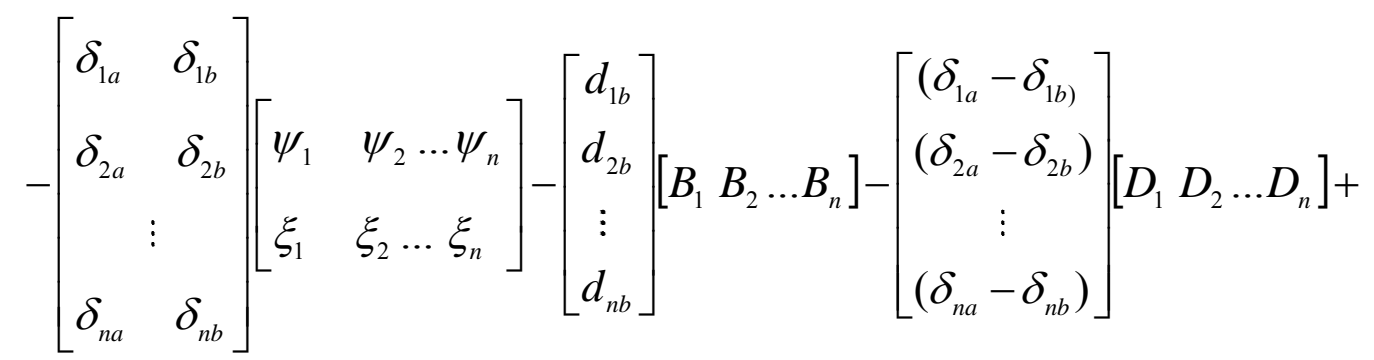

$$
\begin{aligned}
& +\left[\begin{array}{cc}
\psi_{1} & \xi_{1} \\
\psi_{2} & \xi_{2} \\
& \vdots \\
\psi_{n} & \xi_{n}
\end{array}\right]\left[\begin{array}{l}
\left(\delta_{a a}-\delta_{a b}\right) \\
\left(\delta_{b a}-\delta_{b b}\right)
\end{array}\right]\left[\begin{array}{ll}
D_{1} D_{2} \ldots D_{n}
\end{array}\right]
\end{aligned}
$$

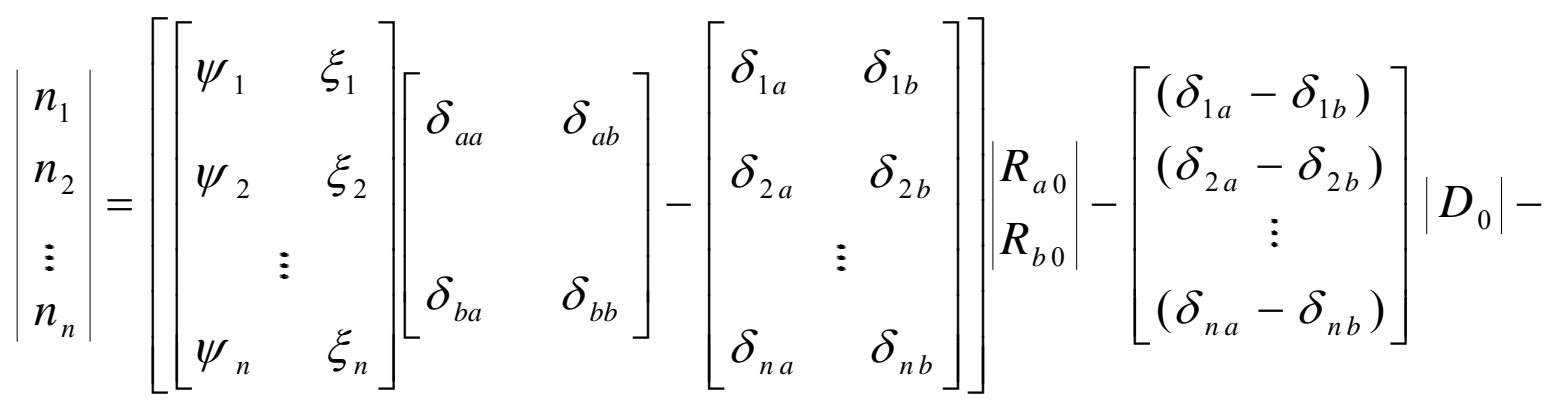

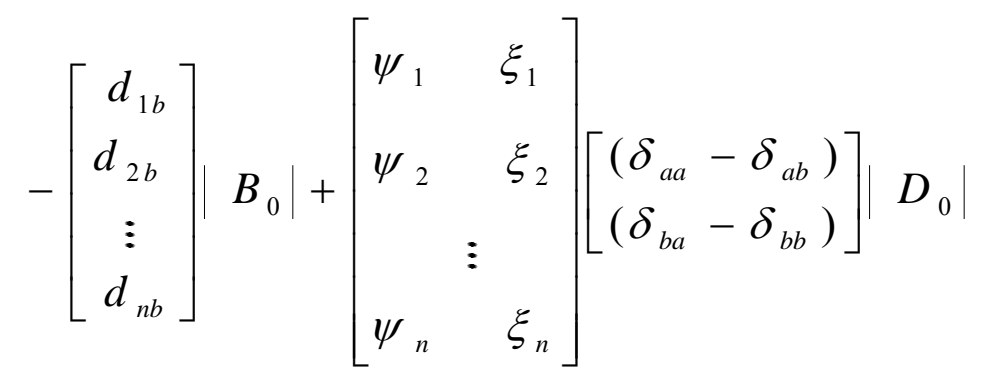

Solving the matrix above are obtained $\mathrm{R}_{1}, \mathrm{R}_{2}, \mathrm{R}_{3}, \ldots$ and $R_{6}$. With the equations (12) and (13) are obtained $\mathrm{R} a$ and $\mathrm{R} b$. The lateral displacements are obtaining whit equation (5). The reactions and lateral displacements are shown in Table 7.

Fig. 5 shows the lateral displacement-depth diagram, while Fig. 6 shows the lateral contact pressure-depth diagram.

4.2.2 Ultimate lateral resistance in static condition

In Fig. 5, the depth of the passive zone, ZP is $4.40 \mathrm{~m}$, so the calculation of the ultimate lateral resistance of the pier is considered up to the bottom of the dowel 5, at a depth of $4.33 \mathrm{~m}$. 
Table 6 Vectors $\mathrm{N}_{\mathrm{i}}$ and $\Delta_{\mathrm{i}}$ Reactions Rao and $\mathbf{R b o}$.

\begin{tabular}{lll}
\hline Vector Ni & Vector $\Delta \mathrm{i}$ & \\
\hline$(\mathrm{m})$ & $(\mathrm{m})$ & Rao $=303.20 \mathrm{kN}$ \\
$9.3750 \mathrm{E}-03$ & $8.1867 \mathrm{E}-05$ & \\
$1.3499 \mathrm{E}-02$ & $1.2408 \mathrm{E}-04$ & $\mathrm{R} b \mathrm{O}=-73.20 \mathrm{kN}$ \\
$1.1844 \mathrm{E}-02$ & $1.3760 \mathrm{E}-04$ & \\
$9.1850 \mathrm{E}-03$ & $1.3029 \mathrm{E}-04$ & \\
$6.0153 \mathrm{E}-03$ & $1.0278 \mathrm{E}-04$ & \\
$2.7172 \mathrm{E}-03$ & $5.5790 \mathrm{E}-05$ & \\
\hline
\end{tabular}

Soil structure interaction matrix equation (EMISE):

$(\mathrm{m} / \mathrm{kN})$

$(\mathrm{kN})$

(m)

\begin{tabular}{|l|l|l|l|l|l|l|l|l|}
\hline $5.9830 \mathrm{E}-05$ & $4.7591 \mathrm{E}-05$ & $2.9068 \mathrm{E}-05$ & $2.1374 \mathrm{E}-05$ & $1.5480 \mathrm{E}-05$ & $8.2919 \mathrm{E}-06$ & $\mathrm{R}_{1}$ & & $9.4569 \mathrm{E}-03$ \\
\hline $4.5005 \mathrm{E}-05$ & $8.1769 \mathrm{E}-05$ & $5.8759 \mathrm{E}-05$ & $3.6777 \mathrm{E}-05$ & $2.5417 \mathrm{E}-05$ & $1.3626 \mathrm{E}-05$ & $\mathrm{R}_{2}$ & $1.3623 \mathrm{E}-02$ \\
\hline $2.8263 \mathrm{E}-05$ & $5.8364 \mathrm{E}-05$ & $8.2172 \mathrm{E}-05$ & $5.6872 \mathrm{E}-05$ & $3.2369 \mathrm{E}-05$ & $1.6469 \mathrm{E}-05$ & $\mathrm{R}_{3}$ & $1.1982 \mathrm{E}-02$ \\
\hline $2.0981 \mathrm{E}-05$ & $3.6262 \mathrm{E}-05$ & $5.6685 \mathrm{E}-05$ & $7.8862 \mathrm{E}-05$ & $4.9220 \mathrm{E}-05$ & $2.0425 \mathrm{E}-05$ & $\mathrm{R}_{4}$ & \\
\hline $1.5152 \mathrm{E}-05$ & $2.4567 \mathrm{E}-05$ & $3.0988 \mathrm{E}-05$ & $4.5690 \mathrm{E}-05$ & $6.5732 \mathrm{E}-05$ & $3.1406 \mathrm{E}-05$ & $\mathrm{R}_{5}$ & \\
\hline $8.1698 \mathrm{E}-06$ & $1.3250 \mathrm{E}-05$ & $1.6041 \mathrm{E}-05$ & $1.9603 \mathrm{E}-05$ & $3.1381 \mathrm{E}-05$ & $4.4522 \mathrm{E}-05$ & $\mathrm{R}_{6}$ & & $2.1181 \mathrm{E}-03$ \\
\hline
\end{tabular}

Table 7 Reactions and lateral displacements.

\begin{tabular}{llll}
\hline Dowel & zi $(\mathrm{m})$ & $\mathrm{Ri}(\mathrm{kN})$ & $\delta \mathrm{i}(\mathrm{m})$ \\
\hline$a$ & 0.375 & 152.321 & $1.8558 \mathrm{E}-02$ \\
1 & 1.125 & 50.946 & $1.5112 \mathrm{E}-02$ \\
2 & 1.833 & 97.132 & $1.1835 \mathrm{E}-02$ \\
3 & 2.500 & 37.006 & $8.7400 \mathrm{E}-03$ \\
4 & 3.167 & 27.646 & $5.6412 \mathrm{E}-03$ \\
5 & 3.917 & 13.682 & $2.1533 \mathrm{E}-03$ \\
6 & 4.750 & -11.123 & $-1.7232 \mathrm{E}-03$ \\
$b$ & 5.583 & -137.611 & $-5.6005 \mathrm{E}-03$ \\
\hline
\end{tabular}

$\mathrm{Ri}$ is the reaction of soil-foundation contact in the dowel $\mathrm{i}$ and $\delta i$ is the lateral displacement of the pier at the center of dowel $i$.

With equation (3), it is obtained the ultimate lateral resistance of the pier shown in Table 8 .

4.2.3 Factor of Safety against the Foundation Passive Failure

$$
F S=\frac{1264.51}{378.73}=3.34
$$

\subsubsection{Discussion of Results}

The safety factor obtained against the foundation passive failure is satisfactory.

It was obtained a maximum lateral displacement of $18.6 \mathrm{~mm}$ for this foundation, so that for a depth $\mathrm{ZP}$ of $4.4 \mathrm{~m}$ there is a pier rotation of $0.24^{\circ}$ with respect to the vertical, so that the foundation meets the maximum lateral displacement and tilt.

The definition of the factor of safety against passive failure according to Eq. (4) is correct since the $\sum_{0}^{Z P} R_{i}=$ $378.73 \mathrm{kN}$ is higher by $65 \%$ than the horizontal load P of $230 \mathrm{kN}$, applied to the head of the pile. We conclude that the foundation is stable and is not suitable to reduce the diameter of the pier.

\section{Displacement (cm)}

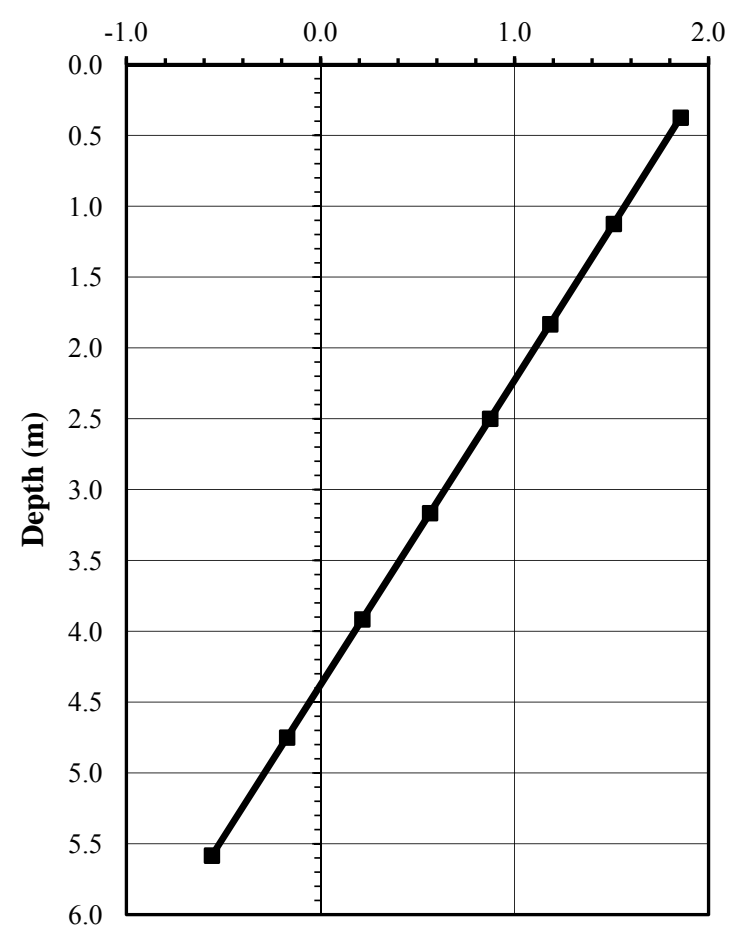

Fig. 5 Lateral displacement diagram. 


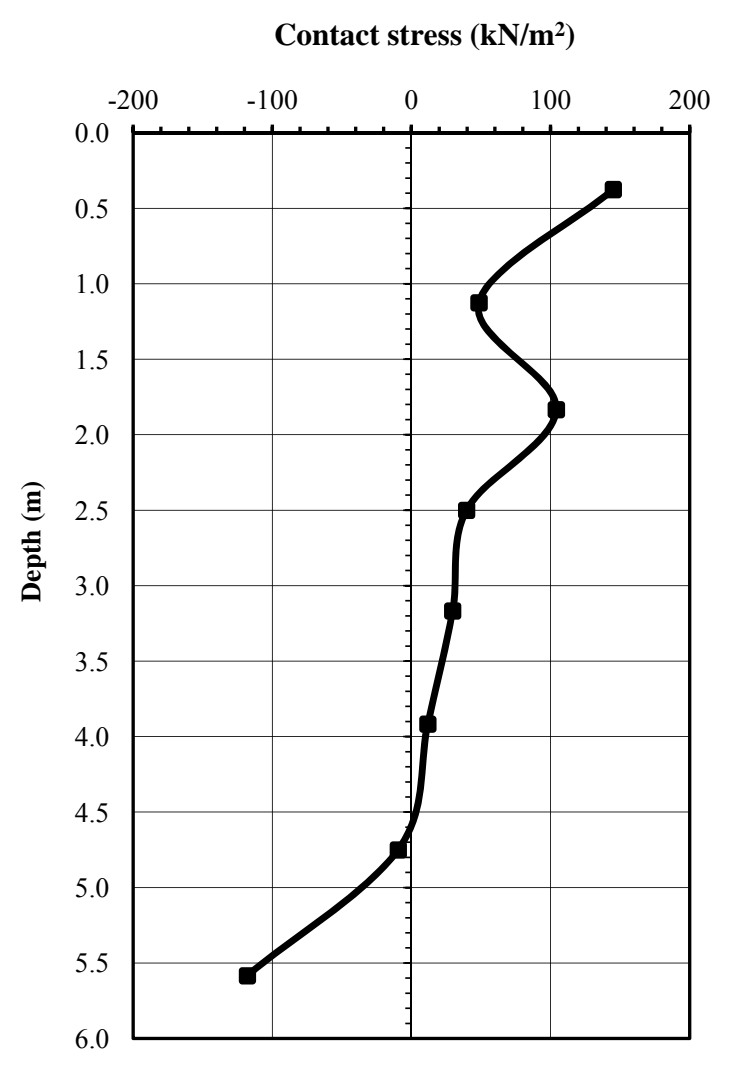

Fig. 6 Lateral contact pressure diagram.

\section{Example of a Pier in Seismic Condition}

\subsection{Statement of the Problem}

The stability analysis for the pier was developed with the following features:

Foundation pier using Case II, EI $=4.8168 \mathrm{E}+06$ $\mathrm{kN} / \mathrm{m}^{2}$ ( $E$ is the Young's modulus of reinforced concrete and $I$ is the moment of inertia of the cross section of the pier).

$P=400 \mathrm{kN} ; M=0.0 \mathrm{kN}-\mathrm{m} ; d=0.00 \mathrm{~m} ; D=1.40 \mathrm{~m} ;$ $D f=15.00 \mathrm{~m}$. Considering subsoil foundation characteristics shown in Table 9, with the water level on the ground surface and hydrostatic water condition, and Poisson's ratio of subsoil, $v=0.5$.

When estimating the drag forces exerted by the soil mass against the pier during the earthquake, the seismic horizontal displacements of the soil mass shown in Table 10 were considered. It is considered a permitted maximum lateral displacement of $10 \mathrm{~mm}$ and an inclination with respect to the vertical of no more than $1^{\circ}$.

Table 8 Calculation of the ultimate lateral resistance in static condition.

\begin{tabular}{|c|c|c|c|c|c|c|c|c|c|c|}
\hline \multirow{2}{*}{ Dowel } & $\mathrm{Hi}$ & $R i$ & $\gamma_{m}$ & $C$ & $\varphi$ & \multirow{2}{*}{$N \varphi$} & $\sigma_{z M}^{\prime}$ & $\Delta Q_{L U}$ & $\Sigma \Delta Q_{L U}$ & $\Sigma \Delta R i$ \\
\hline & $\overline{(m)}$ & $(\mathrm{kN})$ & $\left(\mathrm{kN} / \mathrm{m}^{3}\right)$ & $\left(\mathrm{kN} / \mathrm{m}^{2}\right)$ & $\left({ }^{0}\right)$ & & $\left(\mathrm{kN} / \mathrm{m}^{2}\right)$ & $(\mathrm{kN})$ & $(\mathrm{kN})$ & $(\mathrm{kN})$ \\
\hline $\bar{a}$ & 0.75 & 152.32 & 18.142 & 15.298 & 34 & 3.54 & 6.80 & 85.689 & 85.689 & 152.321 \\
\hline 1 & 0.75 & 50.95 & 18.142 & 15.298 & 34 & 3.54 & 20.41 & 136.224 & 221.913 & 203.267 \\
\hline 2 & 0.67 & 97.13 & 18.338 & 18.437 & 34 & 3.54 & 33.33 & 174.746 & 396.659 & 300.399 \\
\hline 3 & 0.67 & 37.01 & 18.338 & 18.437 & 34 & 3.54 & 45.55 & 215.106 & 611.765 & 337.405 \\
\hline 4 & 0.67 & 27.65 & 18.338 & 18.437 & 34 & 3.54 & 57.78 & 255.467 & 867.232 & 365.051 \\
\hline 5 & 0.83 & 13.68 & 19.123 & 19.613 & 35 & 3.69 & 71.86 & 397.277 & $1,264.509$ & 378.734 \\
\hline \multicolumn{2}{|c|}{$\Sigma R i(\mathrm{kN})=$} & 378.73 & & & & \multicolumn{2}{|c|}{$Q_{L u}(\mathrm{kN})=$} & $1,264.509$ & & \\
\hline
\end{tabular}

Table 9 Foundation subsoil characteristics corresponding to Example 5.

\begin{tabular}{llllll}
\hline & Depth $(\mathrm{m})$ & Description & $\gamma_{m}$ & $C$ & $\varphi$ \\
\cline { 4 - 6 } Ground and water label & 0.00 & & $\left(\mathrm{kN} / \mathrm{m}^{3}\right)$ & $\left(\mathrm{kN} / \mathrm{m}^{2}\right)$ & $\left(^{\mathrm{O}}\right)$ \\
\hline & 3.50 & Saturated fine soil & 16.181 & 39.227 & 30 \\
& 6.00 & Saturated fine soil & 12.945 & 34.323 & 28 \\
& 8.00 & Saturated fine soil & 11.768 & 31.381 & 26 \\
& 10.50 & Saturated fine soil & 13.729 & 41.678 & 28 \\
& 12.00 & Saturated fine soil & 11.768 & 32.362 & 26 \\
& 14.00 & Saturated fine soil & 13.729 & 35.304 & 28 \\
& 16.00 & Saturated fine soil & 14.220 & 40.207 & 30 \\
& 18.00 & Resistant stratum & 15.691 & - & - \\
\hline
\end{tabular}


Table 10 Seismic displacement and characteristics of the soil mass, $\delta_{S i}$.

\begin{tabular}{llllllc}
\hline Dowel & Thickness $(\mathrm{m})$ & Unit weight $\left(\mathrm{kN} / \mathrm{m}^{3}\right)$ & $\mu_{i}\left(\mathrm{kN} / \mathrm{m}^{2}\right)$ & $M h i\left(\mathrm{~m}^{2} / \mathrm{kN}\right)$ & $Z i(\mathrm{~m})$ & $\delta_{S i}(\mathrm{~m})$ \\
\hline$a$ & 1.50 & 16.181 & 14,700 & $2.2676 \mathrm{E}-05$ & 0.75 & $2.3870 \mathrm{E}-02$ \\
1 & 2.00 & 16.181 & 14,700 & $2.2676 \mathrm{E}-05$ & 2.50 & $2.3529 \mathrm{E}-02$ \\
2 & 2.50 & 12.945 & 3,730 & $8.9366 \mathrm{E}-05$ & 4.75 & $2.0854 \mathrm{E}-02$ \\
3 & 2.00 & 11.768 & 2,750 & $1.2121 \mathrm{E}-04$ & 7.00 & $1.5060 \mathrm{E}-02$ \\
4 & 2.50 & 13.729 & 6,370 & $5.2329 \mathrm{E}-05$ & 9.25 & $9.5442 \mathrm{E}-03$ \\
5 & 1.50 & 11.768 & 24,520 & $1.3594 \mathrm{E}-05$ & 11.25 & $7.0659 \mathrm{E}-03$ \\
6 & 2.00 & 13.729 & 8,340 & $3.9968 \mathrm{E}-05$ & 13.00 & $5.2276 \mathrm{E}-03$ \\
$b$ & 1.00 & 14.220 & 8,830 & $3.7750 \mathrm{E}-05$ & 14.50 & $3.7648 \mathrm{E}-03$ \\
\hline
\end{tabular}

$\mu_{i}$ is the shear modulus of dowel $i, M h i$ is the horizontal deformation modulus of dowel $i, Z i$ is the depth at the center of dowel $i$ and $\delta_{S i}$ is the horizontal seismic displacement of the soil mass at the center of dowel $i$.

\subsection{Solution}

\subsubsection{Soil-Foundation Structure Interaction}

The soil-foundation structure interaction was conducted according to Medina [4]. The foundation pier was divided into eight segments: $a, 1,2,3,4,5,6$ and $b$. We worked with $\Delta x=2.10 \mathrm{~m}$ and six sections in the soil mass: A, B, C, D, E and F. Discretization of the foundation and soil mass are shown in Table 11.

By applying the flexibility method (Fig. 7) Medina [4], it is obtained the flexibility matrix equation that corresponds to case II, equation (15).

Observe that with matrix Equations (5) and (15) there are $2 n+3$ equations with $2 n+5$ unknowns, therefore the two remaining equations are obtained from the sum of moments at supports $a$ and $b$ with which the system of equations can be resolved, obtaining equations (16) to (25).

Table 11 Soil mass and pier discretization.

\begin{tabular}{|c|c|c|c|c|}
\hline Dowel & Thickness (m) & $Z i(\mathrm{~m})$ & $\operatorname{Mhi}\left(\mathrm{m}^{2} / \mathrm{kN}\right)$ & $\Delta \delta_{\mathrm{Si}}(\mathrm{m})$ \\
\hline$a$ & 1.50 & 0.75 & $2.2676 \mathrm{E}-05$ & $0.0000 \mathrm{E}+00$ \\
\hline 1 & 2.00 & 2.50 & $2.2676 \mathrm{E}-05$ & $2.2176 \mathrm{E}-03$ \\
\hline 2 & 2.50 & 4.75 & 8.9366E-05 & $2.8330 \mathrm{E}-03$ \\
\hline 3 & 2.00 & 7.00 & $1.2121 \mathrm{E}-04$ & $3.2908 \mathrm{E}-04$ \\
\hline 4 & 2.50 & 9.25 & $5.2329 \mathrm{E}-05$ & $-1.8972 \mathrm{E}-03$ \\
\hline 5 & 1.50 & 11.25 & $1.3594 \mathrm{E}-05$ & $-1.4511 \mathrm{E}-03$ \\
\hline 6 & 2.00 & 13.00 & $3.9968 \mathrm{E}-05$ & $-7.3052 \mathrm{E}-04$ \\
\hline$b$ & 1.00 & 14.50 & $3.7750 \mathrm{E}-05$ & $0.0000 \mathrm{E}+00$ \\
\hline
\end{tabular}

$\Delta \delta_{\text {si }}$ is the soil mass relative seismic displacement with respect to dowels a and $b$.

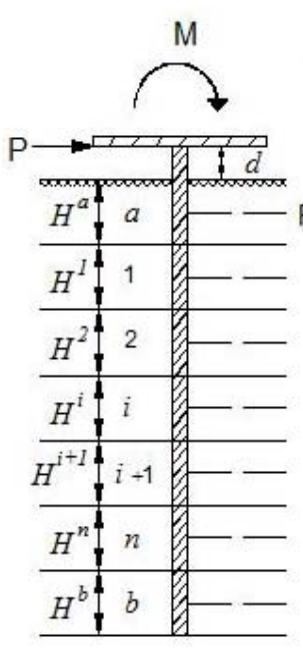

(a)

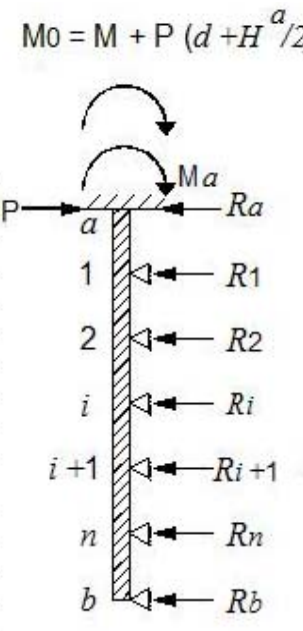

(b)

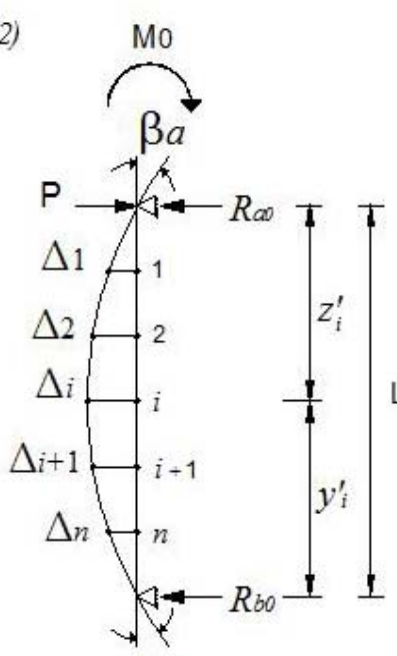

$\beta b$

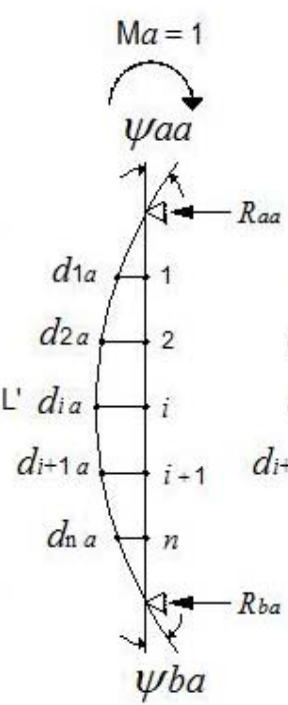

(d)

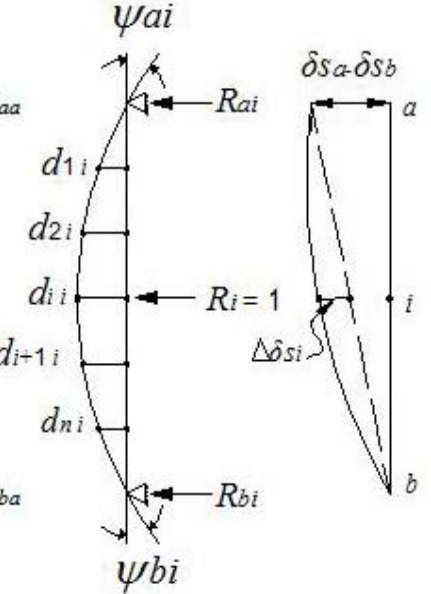

(e)

Fig. 7 Application of the flexibilities method: a) real foundation; b) discreteness of foundation; c) condition $R_{i}=0$; d) condition $M a=1$; e) condition $R_{i}=1$; f) relative seismic displacement of soil mass. 


$$
\left[\begin{array}{ccccc}
\psi_{a a} & \psi_{a 1} & \psi_{a 2} & \ldots & \psi_{a n} \\
d_{1 a} & d_{11} & d_{12} & \ldots & d_{1 n} \\
d_{2 a} & d_{21} & d_{22} & \ldots & d_{2 n} \\
d_{n a} & d_{n 1} & d_{n 2} & \ldots & d_{n n}
\end{array}\right]\left|\begin{array}{c}
M_{a} \\
R_{1} \\
R_{2} \\
\vdots \\
R_{n}
\end{array}\right|=\left|\begin{array}{c}
\beta_{a} \\
\Delta_{1} \\
\Delta_{2} \\
\vdots \\
\Delta_{n}
\end{array}\right|+\left|\begin{array}{c}
0 \\
\delta_{1}^{A} \\
\delta_{2}^{A} \\
\vdots \\
\delta_{n}^{A}
\end{array}\right|-\left|\begin{array}{c}
\theta_{a} \\
\delta_{1} \\
\delta_{2} \\
\vdots \\
\delta_{n}
\end{array}\right|
$$

Where Ma is the moment at the head of the pier; $\beta_{a}$ is the rotation of support $a$ for condition $\mathrm{R}_{\mathrm{i}}=0, \theta_{a}$ is the rotation of head of pier for deformation of material where the pier is fitted; $\psi_{a i}$ is the rotation of the support $a$ due to a unit load applied at $\mathrm{i}$ (condition $\mathrm{R}_{\mathrm{i}}=1$ ); $\psi_{a a}$ is the rotation of the support $a$ due to a unit moment applied at $a$ (condition $\left.\mathrm{M}_{a}=1\right)$.

$$
\begin{aligned}
& {\left[\left[\begin{array}{cccc}
\delta_{11} & \delta_{12} & \ldots & \delta_{1 n} \\
\delta_{21} & \delta_{22} & \ldots & \delta_{2 n} \\
& \vdots & & \\
\delta_{n 1} & \delta_{n 2} & \ldots & \delta_{n n}
\end{array}\right]+\left[\begin{array}{cccc}
d_{11} & d_{12} & \ldots & d_{1 n} \\
d_{21} & d_{22} & \ldots & d_{2 n} \\
& \vdots & & \\
d_{n 1} & d_{n 2} & \ldots & d_{n n}
\end{array}\right]+\left[\begin{array}{cccc}
m_{11} & m_{12} & \ldots & m_{1 n} \\
m_{21} & m_{22} & \ldots & m_{2 n} \\
\vdots & & \\
m_{n 1} & m_{n 2} & \ldots & m_{n n}
\end{array}\right]|| \begin{array}{c}
R_{1} \\
R_{2} \\
\vdots \\
R_{n}
\end{array}|=| \begin{array}{c}
n_{1} \\
n_{2} \\
\vdots \\
n_{n}
\end{array}|+| \begin{array}{c}
\Delta_{1} \\
\Delta_{2} \\
\vdots \\
\Delta_{n}
\end{array}|+| \begin{array}{c}
\Delta \delta_{S 1} \\
\Delta \delta_{S 2} \\
\vdots \\
\Delta \delta_{S n}
\end{array} \mid\right.} \\
& {\left[\begin{array}{cccc}
m_{11} & m_{12} & \ldots & m_{1 n} \\
m_{21} & m_{22} & \ldots & m_{2 n} \\
m_{n 1} & m_{n 2} \ldots & m_{n n}
\end{array}\right]=\left[\begin{array}{cc}
\psi_{1} & \xi_{1} \\
\psi_{2} & \xi_{2} \\
& \vdots \\
\psi_{n} & \xi_{n}
\end{array}\right]\left[\begin{array}{cc}
\delta_{a a} & \delta_{a b} \\
\delta_{b a} & \delta_{b b}
\end{array}\right]\left[\begin{array}{llll}
\psi_{1} & \psi_{2} & \ldots & \psi_{n} \\
\xi_{1} & \xi_{2} & \ldots & \xi_{n}
\end{array}\right]-\left[\begin{array}{cc}
\psi_{1} & \xi_{1} \\
\psi_{2} & \xi_{2} \\
\vdots & \\
\psi_{n} & \xi_{n}
\end{array}\right]\left[\begin{array}{lll}
\delta_{a 1} & \delta_{a 2} \ldots & \delta_{a n} \\
\delta_{b 1} & \delta_{b 2} \ldots & \delta_{b n}
\end{array}\right]-}
\end{aligned}
$$

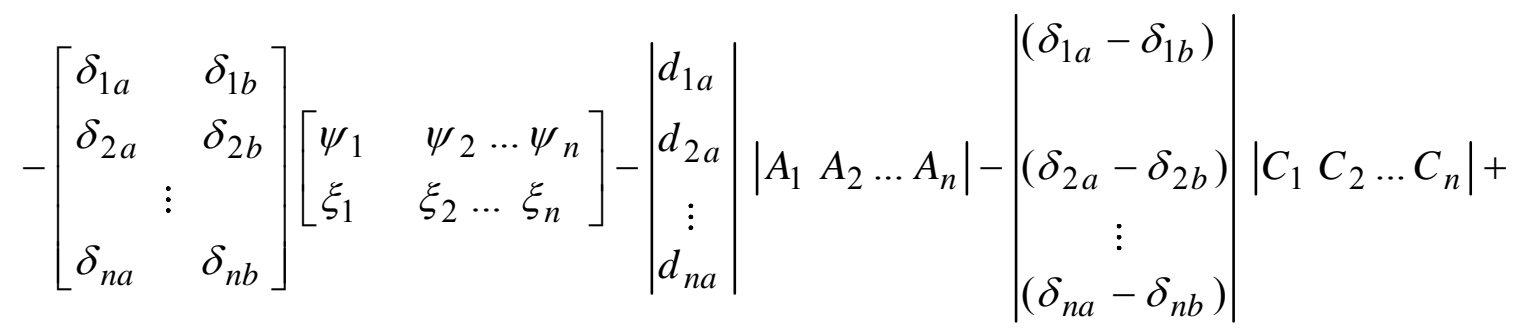

$$
\begin{aligned}
& +\left[\begin{array}{ccc}
\psi_{1} & & \xi_{1} \\
\psi_{2} & & \xi_{2} \\
& \vdots & \\
\psi_{n} & & \xi_{n}
\end{array}\right]\left|\begin{array}{l}
\left(\delta_{a a}-\delta_{a b}\right) \\
\left(\delta_{b a}-\delta_{b b}\right)
\end{array}\right|\left|C_{1} C_{2} \ldots C_{n}\right|
\end{aligned}
$$

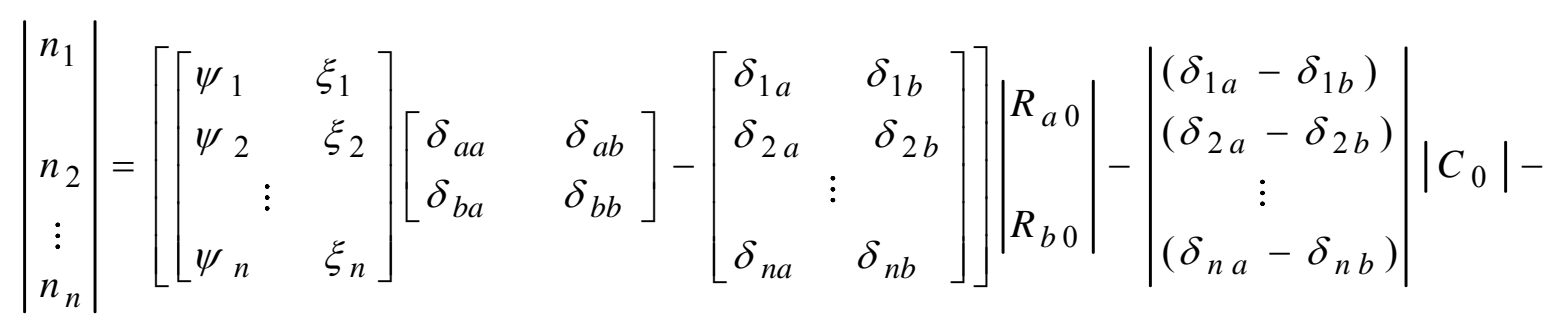




$$
\begin{gathered}
-\left|\begin{array}{c}
d_{1} a \\
d_{2} a \\
\vdots \\
d_{n a}
\end{array}\right| A_{0} \mid+ \\
A_{0}=\frac{\beta_{a}+\gamma_{s a}-C_{\theta a} M_{0}}{\psi_{a a}+C_{\theta a}} \\
A_{i}=\frac{\psi_{a i}}{\psi_{a a}+C_{\theta a}} \\
C_{0}=A_{0} / L^{\prime} \\
C_{i}=A_{i} / L^{\prime} \\
M_{a}=A_{o}-\left(A_{1} R_{1}+A_{2} R_{2}+\ldots+A_{n} R_{n}\right) \\
R_{a}=R_{a 0}-\left(\psi_{1} R_{1}+\psi_{2} R_{2}+\ldots+\psi_{n} R_{n}\right)+M_{a} / L^{\prime} \\
R_{b}=R_{b 0}-\left(\xi_{1} R_{1}+\xi_{2} R_{2}+\ldots+\xi_{n} R_{n}\right)-M_{a} / L^{\prime}
\end{gathered}
$$

The problem was solved by a computer program developed in a spreadsheet.

Table 12 shows the unit lateral displacements matrix $\left[\delta_{j i}\right]$. Table 13 shows the matrix $\left[d_{j i}\right]$; Table 14 show the matrix $\left[m_{j i}\right]$; Table 15 shows the vectors $\mathrm{N}_{\mathrm{i}}, \Delta \mathrm{i}$ and $\Delta \delta_{\mathrm{Si}}$.

Solving the matrix (EMISE) are obtained R1, R2, $\mathrm{R} 3, \ldots$ and R6. With the equations (23), (24) and (25) are obtaining $\mathrm{Ma}, \mathrm{Ra}$ and $\mathrm{Rb}$. The lateral displacements are obtaining whit equation (5). The reactions and lateral displacements are shown in Table 17.

Fig. 8 shows the lateral displacement-depth diagram, while Fig. 9 shows the lateral contact pressure-depth

$$
\left.\begin{array}{l}
\xi_{1} \\
\xi_{2} \\
\xi_{n}
\end{array}\right]\left|\begin{array}{l}
\left(\delta_{a a}-\delta_{a b}\right) \\
\left(\delta_{b a}-\delta_{b b}\right)
\end{array}\right|\left|C_{0}\right|
$$

diagram.

$\mathrm{M} a=-1034.071 \mathrm{kN} / \mathrm{m} ; \theta_{a}=-8.8544 \mathrm{E}-04 \mathrm{rad}$. Table 18 shows the horizontal stress increment matrix indicated by the pier in seismic condition.

5.2.2 Lateral Bearing Capacity in Seismic Condition

In Fig. 8, the depth of the passive zone $Z P$ is $8.50 \mathrm{~m}$, so the calculation of the lateral bearing capacity is considered down to the bottom of the dowel 3 at a depth of $8.00 \mathrm{~m}$.

The lateral bearing capacity of the pier is obtaining from equation (3). Table 19 shows the calculation of the lateral bearing capacity of the pier. Hydraulic pressure is calculated on the center of the section, and at the center of each of the dowels with equation (26),

$$
\mathrm{u}=\mathrm{uh}+\Delta \mathrm{u}
$$

where $u$ is the hydraulic pressure, $u$ is the hydrostatic pressure and $\Delta \mathrm{u}$ is the increase in hydrostatic pressure generated in seismic condition. $\Delta \mathrm{u}$ is obtained from Table 18 and it is considered on section A.

5.2.3 Factor of Safety against the Foundation Passive Failure

$$
\text { Fs }=\frac{1718.32}{558.70}=3.08
$$

\subsubsection{Discussion of results}

The $558.70 \mathrm{kN}$ is higher by $40 \%$ than the horizontal load $\mathrm{P}$ of $400 \mathrm{kN}$ applied to the head of the foundation pier.

Table 12 Unitary lateral displacements matrix, $\left[\delta_{j i}\right]$ (m/kN).

\begin{tabular}{llllllll}
\hline$a$ & 1 & 2 & 3 & 4 & 5 & 6 & $b$ \\
\hline $8.4242 \mathrm{E}-06$ & $2.0443 \mathrm{E}-06$ & $6.0611 \mathrm{E}-07$ & $2.6068 \mathrm{E}-07$ & $1.2780 \mathrm{E}-07$ & $7.0637 \mathrm{E}-08$ & $4.4137 \mathrm{E}-08$ & $2.9907 \mathrm{E}-08$ \\
$1.9302 \mathrm{E}-06$ & $7.0450 \mathrm{E}-06$ & $1.3420 \mathrm{E}-06$ & $4.4180 \mathrm{E}-07$ & $2.0016 \mathrm{E}-07$ & $1.0567 \mathrm{E}-07$ & $6.4058 \mathrm{E}-08$ & $4.2368 \mathrm{E}-08$ \\
$2.3349 \mathrm{E}-06$ & $5.0529 \mathrm{E}-06$ & $2.4603 \mathrm{E}-05$ & $4.9158 \mathrm{E}-06$ & $1.6949 \mathrm{E}-06$ & $8.0956 \mathrm{E}-07$ & $4.6488 \mathrm{E}-07$ & $2.9527 \mathrm{E}-07$ \\
$1.3847 \mathrm{E}-06$ & $2.3616 \mathrm{E}-06$ & $6.9861 \mathrm{E}-06$ & $3.7143 \mathrm{E}-05$ & $6.9406 \mathrm{E}-06$ & $2.4607 \mathrm{E}-06$ & $1.2938 \mathrm{E}-06$ & $7.7848 \mathrm{E}-07$ \\
$2.9162 \mathrm{E}-07$ & $4.5841 \mathrm{E}-07$ & $9.9247 \mathrm{E}-07$ & $2.8589 \mathrm{E}-06$ & $1.4357 \mathrm{E}-05$ & $3.2651 \mathrm{E}-06$ & $1.3177 \mathrm{E}-06$ & $7.1775 \mathrm{E}-07$ \\
$4.2348 \mathrm{E}-08$ & $6.3658 \mathrm{E}-08$ & $1.2490 \mathrm{E}-07$ & $2.7863 \mathrm{E}-07$ & $9.4655 \mathrm{E}-07$ & $4.6605 \mathrm{E}-06$ & $1.0976 \mathrm{E}-06$ & $4.1848 \mathrm{E}-07$ \\
$7.7505 \mathrm{E}-08$ & $1.1291 \mathrm{E}-07$ & $2.0928 \mathrm{E}-07$ & $4.2661 \mathrm{E}-07$ & $1.0214 \mathrm{E}-06$ & $3.0313 \mathrm{E}-06$ & $1.2236 \mathrm{E}-05$ & $3.6144 \mathrm{E}-06$ \\
$4.9908 \mathrm{E}-08$ & $7.0991 \mathrm{E}-08$ & $1.2641 \mathrm{E}-07$ & $2.4474 \mathrm{E}-07$ & $5.2974 \mathrm{E}-07$ & $1.1734 \mathrm{E}-06$ & $3.9160 \mathrm{E}-06$ & $1.4380 \mathrm{E}-05$ \\
\hline
\end{tabular}


Table 13 Matrix, $\left[d_{j i}\right](\mathrm{rad} / \mathbf{k N} ; \mathbf{m} / \mathbf{k N})$.

\begin{tabular}{lllllll}
\hline$a$ & 1 & 2 & 3 & 4 & 5 & 6 \\
\hline $9.5153 \mathrm{E}-07$ & $1.3608 \mathrm{E}-06$ & $2.3063 \mathrm{E}-06$ & $2.5066 \mathrm{E}-06$ & $2.1336 \mathrm{E}-06$ & $1.4598 \mathrm{E}-06$ & $7.0515 \mathrm{E}-07$ \\
$1.3608 \mathrm{E}-06$ & $2.2195 \mathrm{E}-06$ & $3.9046 \mathrm{E}-06$ & $4.2854 \mathrm{E}-06$ & $3.6630 \mathrm{E}-06$ & $2.5109 \mathrm{E}-06$ & $1.2138 \mathrm{E}-06$ \\
$2.3063 \mathrm{E}-06$ & $3.9046 \mathrm{E}-06$ & $7.6550 \mathrm{E}-06$ & $8.8185 \mathrm{E}-06$ & $7.6890 \mathrm{E}-06$ & $5.3160 \mathrm{E}-06$ & $2.5790 \mathrm{E}-06$ \\
$2.5066 \mathrm{E}-06$ & $4.2854 \mathrm{E}-06$ & $8.8185 \mathrm{E}-06$ & $1.1059 \mathrm{E}-05$ & $1.0110 \mathrm{E}-05$ & $7.1274 \mathrm{E}-06$ & $3.4857 \mathrm{E}-06$ \\
$2.1336 \mathrm{E}-06$ & $3.6630 \mathrm{E}-06$ & $7.6890 \mathrm{E}-06$ & $1.0110 \mathrm{E}-05$ & $1.0022 \mathrm{E}-05$ & $7.3861 \mathrm{E}-06$ & $3.6757 \mathrm{E}-06$ \\
$1.4598 \mathrm{E}-06$ & $2.5109 \mathrm{E}-06$ & $5.3160 \mathrm{E}-06$ & $7.1274 \mathrm{E}-06$ & $7.3861 \mathrm{E}-06$ & $5.8609 \mathrm{E}-06$ & $3.0345 \mathrm{E}-06$ \\
$7.0515 \mathrm{E}-07$ & $1.2138 \mathrm{E}-06$ & $2.5790 \mathrm{E}-06$ & $3.4857 \mathrm{E}-06$ & $3.6757 \mathrm{E}-06$ & $3.0345 \mathrm{E}-06$ & $1.6993 \mathrm{E}-06$ \\
\hline
\end{tabular}

Table 14 Matrix, $\left[m_{j i}\right](\mathbf{m} / \mathbf{k N})$.

\begin{tabular}{llllll}
\hline 1 & 2 & 3 & 4 & 5 & 6 \\
\hline $2.4826 \mathrm{E}-06$ & $2.6582 \mathrm{E}-06$ & $2.2512 \mathrm{E}-06$ & $1.9293 \mathrm{E}-06$ & $1.7144 \mathrm{E}-06$ & $1.3125 \mathrm{E}-06$ \\
$7.4930 \mathrm{E}-07$ & $7.7608 \mathrm{E}-07$ & $8.1268 \mathrm{E}-07$ & $1.2678 \mathrm{E}-06$ & $1.8843 \mathrm{E}-06$ & $1.9510 \mathrm{E}-06$ \\
$7.1174 \mathrm{E}-07$ & $7.0744 \mathrm{E}-07$ & $1.0081 \mathrm{E}-06$ & $1.8321 \mathrm{E}-06$ & $2.7807 \mathrm{E}-06$ & $2.8134 \mathrm{E}-06$ \\
$1.2113 \mathrm{E}-06$ & $1.4800 \mathrm{E}-06$ & $2.1608 \mathrm{E}-06$ & $3.3253 \mathrm{E}-06$ & $4.4945 \mathrm{E}-06$ & $4.3537 \mathrm{E}-06$ \\
$1.2276 \mathrm{E}-06$ & $2.0164 \mathrm{E}-06$ & $3.2187 \mathrm{E}-06$ & $4.7972 \mathrm{E}-06$ & $6.2183 \mathrm{E}-06$ & $5.9515 \mathrm{E}-06$ \\
$8.3184 \mathrm{E}-07$ & $1.7259 \mathrm{E}-06$ & $2.8971 \mathrm{E}-06$ & $4.2446 \mathrm{E}-06$ & $5.2957 \mathrm{E}-06$ & $4.3715 \mathrm{E}-06$ \\
\hline
\end{tabular}

Table 15 Vectors $N_{i}, \Delta i$ and $\Delta \delta_{S i} \cdot \beta a$ and Reactions Rao and $R b o$ Constants $A_{0}$ y $C_{0}$.

\begin{tabular}{lllll}
\hline Vector Ni & Vector $\Delta \mathrm{i}$ & Vector $\Delta \delta_{\mathrm{Si}}$ & & \\
\hline $\mathrm{m})$ & $(\mathrm{m})$ & $(\mathrm{m})$ & $\beta a=2.8546 \mathrm{E}-4 \mathrm{rad}$ & $\mathrm{A}_{0}=-7.1306 \mathrm{E}+02$ \\
$3.0330 \mathrm{E}-03$ & $4.0823 \mathrm{E}-04$ & $2.2176 \mathrm{E}-03$ & $\mathrm{R} a \mathrm{o}=421.818 \mathrm{kN}$ & $\mathrm{C}_{0}=-5.1859 \mathrm{E}+01$ \\
$3.1135 \mathrm{E}-03$ & $6.9189 \mathrm{E}-04$ & $2.8330 \mathrm{E}-03$ & & \\
$3.1569 \mathrm{E}-03$ & $7.5198 \mathrm{E}-04$ & $3.2908 \mathrm{E}-04$ & $\mathrm{R} b o=-21.818 \mathrm{kN}$ & \\
$2.8608 \mathrm{E}-03$ & $6.4009 \mathrm{E}-04$ & $-1.8972 \mathrm{E}-03$ & & \\
$2.0936 \mathrm{E}-03$ & $4.3795 \mathrm{E}-04$ & $-1.4511 \mathrm{E}-03$ & & \\
$1.1070 \mathrm{E}-03$ & $2.1155 \mathrm{E}-04$ & $-7.3052 \mathrm{E}-04$ & & \\
\hline
\end{tabular}

Table 16 Vectors Ai and Ci.

\begin{tabular}{lllllll}
\hline & 1 & 2 & 3 & 4 & 5 & 6 \\
\hline $\mathrm{Ai}$ & $6.3065 \mathrm{E}-01$ & $1.0689 \mathrm{E}+00$ & $1.1617 \mathrm{E}+00$ & $9.8883 \mathrm{E}-01$ & $6.7657 \mathrm{E}-01$ & $3.2680 \mathrm{E}-01$ \\
$\mathrm{Ci}$ & $4.5865 \mathrm{E}-02$ & $7.7735 \mathrm{E}-02$ & $8.4486 \mathrm{E}-02$ & $7.1915 \mathrm{E}-02$ & $4.9205 \mathrm{E}-02$ & $2.3768 \mathrm{E}-02$ \\
\hline
\end{tabular}

Soil structure interaction matrix equation (EMISE):

$$
(\mathrm{m} / \mathrm{kN})
$$

(kN)

\begin{tabular}{|l|l|l|l|l|l|l|l|l|}
\hline $1.1747 \mathrm{E}-05$ & $7.9047 \mathrm{E}-06$ & $6.9785 \mathrm{E}-06$ & $5.7925 \mathrm{E}-06$ & $4.3310 \mathrm{E}-06$ & $2.5903 \mathrm{E}-06$ & $\mathrm{R}_{1}$ & $5.6588 \mathrm{E}-03$ \\
\hline $9.7067 \mathrm{E}-06$ & $3.3034 \mathrm{E}-05$ & $1.4547 \mathrm{E}-05$ & $1.0652 \mathrm{E}-05$ & $8.0098 \mathrm{E}-06$ & $4.9949 \mathrm{E}-06$ & $\mathrm{R}_{2}$ & $6.6384 \mathrm{E}-03$ \\
\hline $7.3588 \mathrm{E}-06$ & $1.6512 \mathrm{E}-05$ & $4.9210 \mathrm{E}-05$ & $1.8882 \mathrm{E}-05$ & $1.2369 \mathrm{E}-05$ & $7.5928 \mathrm{E}-06$ & $\mathrm{R}_{3}$ & \multirow{2}{*}{$=$} \\
\hline $5.3327 \mathrm{E}-06$ & $1.0161 \mathrm{E}-05$ & $1.5129 \mathrm{E}-05$ & $2.7705 \mathrm{E}-05$ & $1.5146 \mathrm{E}-05$ & $9.3472 \mathrm{E}-06$ & $\mathrm{R}_{4}$ & $1.6037 \mathrm{E}-03$ \\
\hline $3.8021 \mathrm{E}-06$ & $7.4573 \mathrm{E}-06$ & $1.0625 \mathrm{E}-05$ & $1.3130 \mathrm{E}-05$ & $1.6740 \mathrm{E}-05$ & $1.0084 \mathrm{E}-05$ & $\mathrm{R}_{5}$ & $1.0805 \mathrm{E}-03$ \\
\hline $2.1585 \mathrm{E}-06$ & $4.5142 \mathrm{E}-06$ & $6.8094 \mathrm{E}-06$ & $8.9417 \mathrm{E}-06$ & $1.1361 \mathrm{E}-05$ & $1.8307 \mathrm{E}-05$ & $\mathrm{R}_{6}$ & $5.8801 \mathrm{E}-04$ \\
\hline
\end{tabular}

Table 17 Reactions and lateral displacements.

\begin{tabular}{llll}
\hline Dowel & $Z i(\mathrm{~m})$ & $R i(\mathrm{kN})$ & $\delta h(\mathrm{~m})$ \\
\hline$a$ & 0.75 & -91.384 & $2.0577 \mathrm{E}-04$ \\
1 & 2.50 & 453.341 & $3.1285 \mathrm{E}-03$ \\
2 & 4.75 & 86.102 & $4.1835 \mathrm{E}-03$ \\
3 & 7.00 & 19.258 & $1.8603 \mathrm{E}-03$ \\
4 & 9.25 & -40.071 & $-4.2816 \mathrm{E}-04$ \\
5 & 11.25 & -62.937 & $-2.6916 \mathrm{E}-04$ \\
6 & 13.00 & 8.903 & $4.4393 \mathrm{E}-05$ \\
$b$ & 14.50 & 26.788 & $3.6821 \mathrm{E}-04$ \\
\hline
\end{tabular}

Table 18 shows that under Section A, it is presented the largest increase in the hydraulic pressure. Neglecting the frictional forces of the water flow in the soil mass and the pier contact with the soil foundation, with the excess hydrostatic pressure generated during the earthquake in dowel 1 and under section $\mathrm{A}$, the water would rise $4.9 \mathrm{~m}$ above the ground surface, which is consistent with the removal of water observed in the contact of the pile or pier and 
Displacement (cm)

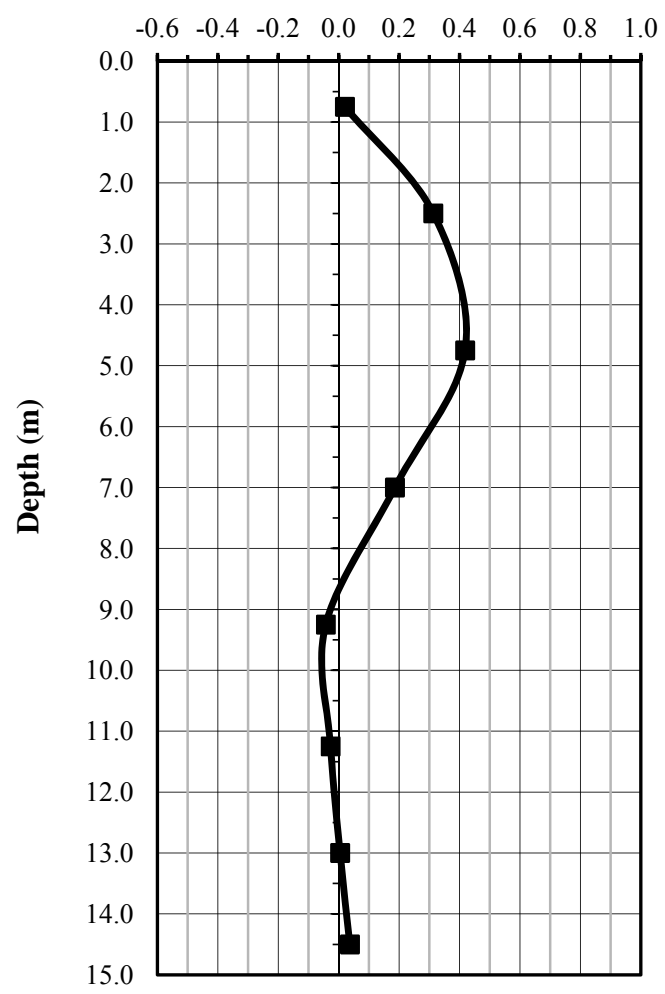

Fig. 8 Lateral displacement diagram.

the soil mass during an earthquake. This phenomenon of ejection of water does not necessarily mean failure of the soil during the earthquake.

Table 18 shows that the excess of hydrostatic pressure generated during the earthquake, decreases rapidly with increasing distance from the shaft of the foundation pier, which justifies the use of Eq. (26), with the estimate of excess hydrostatic pressure under Section A.

From Table 18, it was found that the increase in the hydraulic pressure in the dowel " $a$ " and under the section $\mathrm{A}$ is negative, and this was considered positive for the calculation of effective stress because it can change sign during an earthquake.

The hydraulic pressure in dowels " $a$ " and "1" generated during the earthquake is greater than the total stress in the soil, so that the vertical effective stress is considered zero in the calculation of the ultimate lateral resistance of the subsoil foundation in contact with dowels " $a$ " and "1".

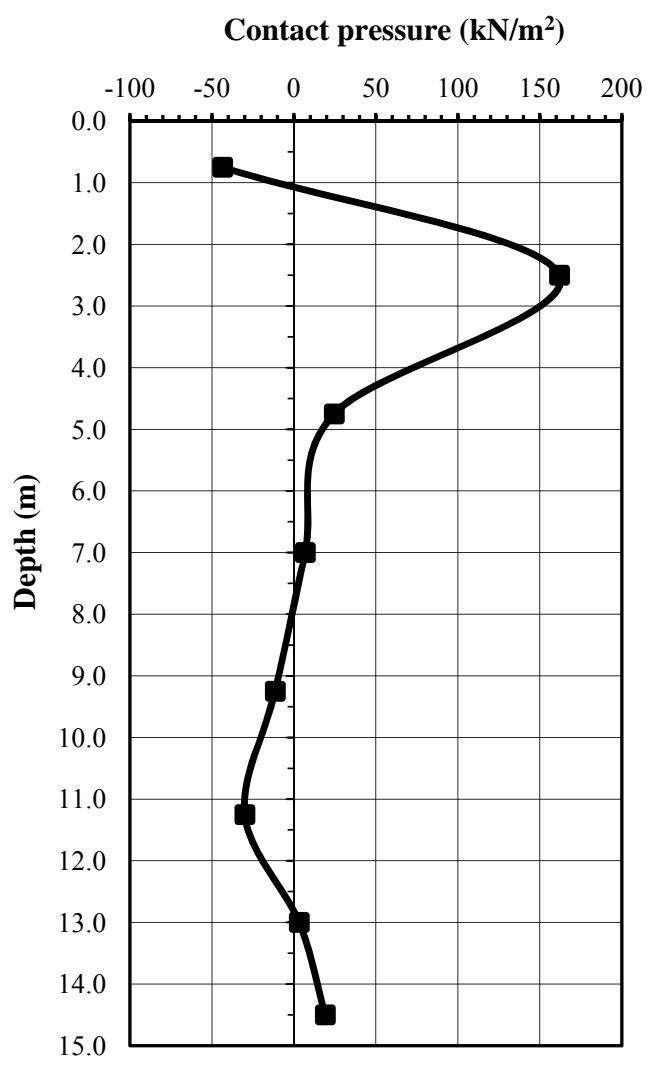

Fig. 9 Lateral contact pressure diagram.

Table 18 Soil mass increased horizontal stress matrix $\left(\mathrm{kN} / \mathrm{m}^{2}\right)$.

\begin{tabular}{llllll}
\hline $\mathrm{A}$ & $\mathrm{B}$ & $\mathrm{C}$ & $\mathrm{D}$ & $\mathrm{E}$ & $\mathrm{F}$ \\
\hline-6.2331 & 3.8568 & 2.7880 & 1.8169 & 1.2263 & 0.8663 \\
48.0806 & 9.5550 & 3.8071 & 2.0672 & 1.2991 & 0.8893 \\
9.9355 & 5.6483 & 3.0207 & 1.7578 & 1.1357 & 0.7940 \\
2.3594 & 1.3986 & 1.2234 & 0.9775 & 0.7580 & 0.5916 \\
-3.9642 & -0.9824 & -0.0163 & 0.3086 & 0.3850 & 0.3731 \\
-8.0163 & -1.4907 & -0.3537 & 0.0298 & 0.1769 & 0.2257 \\
0.7065 & -0.2620 & -0.1531 & -0.0023 & 0.0949 & 0.1450 \\
3.9238 & 0.4653 & 0.0521 & 0.0304 & 0.0693 & 0.1038 \\
\hline
\end{tabular}

The reaction obtained in the slice " $a$ " is negative, which means that in this section the pile charges to the left side, which agrees with the lateral displacement diagram shown in Fig. 8 For this reason in the calculation of $\sum_{0}^{Z P} R_{i}$ the reaction was not considered in dowel " $a$ ".

The factor of safety against passive failure of the foundation is satisfactory.

Maximum lateral displacement of the foundation is $4.2 \mathrm{~mm}$, so that the foundation meets maximum lateral displacement and tilt. 
Table 19 Calculation of lateral bearing capacity in seismic condition.

\begin{tabular}{|c|c|c|c|c|c|c|c|c|c|c|c|c|}
\hline \multirow{2}{*}{ Dowel } & $\mathrm{Hi}$ & $R i$ & $\gamma_{m}$ & C & $\varphi$ & \multirow{2}{*}{$-N \varphi$} & \multirow{2}{*}{$\frac{\sigma_{\mathrm{zM}}}{\left(\mathrm{kN} / \mathrm{m}^{2}\right)}$} & \multirow{2}{*}{$\frac{u}{\left(\mathrm{kN} / \mathrm{m}^{2}\right)}$} & \multirow{2}{*}{$\frac{\sigma_{z M}^{\prime}}{\left(\mathrm{kN} / \mathrm{m}^{2}\right)}$} & \multirow{2}{*}{$\frac{\Delta Q_{L U}}{(\mathrm{kN})}$} & \multirow{2}{*}{$\begin{array}{l}\Sigma \Delta Q_{L U} \\
(\mathrm{kN})\end{array}$} & \multirow{2}{*}{$\begin{array}{l}\Sigma \Delta R i \\
(\mathrm{kN})\end{array}$} \\
\hline & $(\mathrm{m})$ & $(\mathrm{kN})$ & $\left(\mathrm{kN} / \mathrm{m}^{3}\right)$ & $\left(\mathrm{kN} / \mathrm{m}^{2}\right)$ & $\left({ }^{O}\right)$ & & & & & & & \\
\hline $\bar{a}$ & 1.50 & -91.384 & 16.181 & 39.227 & 30 & 3.00 & 12.136 & 13.588 & 0.000 & 285.36 & 285.36 & -91.384 \\
\hline 1 & 2.00 & 453.341 & 16.181 & 39.227 & 30 & 3.00 & 40.452 & 72.597 & 0.000 & 380.48 & 665.84 & 453.341 \\
\hline 2 & 2.50 & 86.102 & 12.945 & 34.323 & 28 & 2.77 & 72.814 & 56.517 & 16.297 & 557.86 & 1223.69 & 539.443 \\
\hline 3 & 2.00 & 19.258 & 11.768 & 31.381 & 26 & 2.56 & 100.763 & 71.006 & 29.757 & 494.63 & 1718.32 & 558.702 \\
\hline \multicolumn{2}{|c|}{$\Sigma R i(\mathrm{kN})=$} & 558.702 & & & & & & $Q_{L U}(\mathrm{kN})$ & & $1,718.32$ & & \\
\hline
\end{tabular}

Therefore, the foundation is stable in seismic condition for lateral passive failure, maximum lateral displacement and permissible tilt.

\section{Conclusions}

It has been explained a procedure for estimating the lateral bearing capacity of foundation piles and piers subjected to lateral loading, both in static and seismic conditions. The method is based upon the Rankine theory of passive earth pressure, and as discussed herein, the frictional force developed in the contact of the shaft of the foundation with the soil is not considered. So the bearing capacity obtained with the method presented here is on the side of safety, i.e., the real capacity will be higher than the calculated. The procedure described has the following advantages:

(1) It can be used in homogeneous soils as in stratified soils;

(2) It is applicable in both static and earthquake condition;

(3) It is easy to program in a spreadsheet and solved with simplicity;

(4) It considers the horizontal drag forces exerted by the soil mass against the foundation during an earthquake;

(5) It can be used easily in the four pile and piers boundary cases;

(6) It considers the pore pressure generated in a fine saturated soil during an earthquake or during a rapid application of the horizontal load.

\section{References}

[1] J. Medina, Interacción sísmica suelo-estructura en pilotes y pilas: Caso I, in: 14th Pan-American Conference on Soil Mechanic and Geotechnical Engineering, Toronto, Ontario, Canada, 2011.

[2] J. Medina, Seismic soil-structure interaction in piles and piers: Case III, in: 14th Pan-American Conference on Soil Mechanic and Geotechnical Engineering, Toronto, Ontario, Canada, 2011.

[3] J. Medina, Seismic soil-structure interaction in piles and piers: Case IV, in: 5th International Conference on Earthquake Geotechnical Engineering, Santiago de Chile, Chile, 2011.

[4] J. Medina, Interacción sísmica suelo-estructura en pilas y pilotes: Caso II, in: Proceedings of the XX Congreso Argentino de Mecánica de Suelos e Ingeniería Geotécnica, Mendoza, Argentina, 2010, pp. 281-288.

[5] K. Terzaghi, Theoretical Soil Mechanics, John Wiley and Sons, New York, 1943.

[6] L. Zeevaert, Foundation Engineering for Difficult Subsoil Conditions, Van Nostrand Reinhold Company, New York, 1983.

[7] J. Medina, Esfuerzo horizontal producido por una carga rectangular horizontal uniforme aplicada en el interior de un sólido, in: Proceedings of XXV Reunión Nacional de la Sociedad Mexicana de Ingeniería Geotécnica, Acapulco, Guerrero, México, 2010, Vol. 3, pp. 871-876. 